\title{
The Use of Online Marketplace Websites in Indonesia: A Study of Consumers' Motives and Gratification
}

https://doi.org/10.3991/ijim.v14i07.11385

\author{
Humaizi ${ }^{\bowtie)}$, Sakhyan Asmara, Rany Listiawati Sis, Muhammad Yusuf \\ Universitas Sumatera Utara, Medan, Indonesia \\ humaizi fisipusu@yahoo.com
}

\begin{abstract}
The rapid development of technology eases people to do many things such as shopping, paying bills, transferring money, and so on. This study is intended to discover consumers' motives and gratifications in using online marketplace websites through uses and gratification theory (UGT). This study employed a quantitative method. The population in this study is undergraduate students of business and economy faculty of Universitas Sumatera Utara who have ever made a purchase at tokopedia.com and bukalapak.com. Accidental and purposive samplings were utilized to determine the samples totaling to 66 respondents. The methods employed to collect the data were survey and questionnaire. Validity and reliability were tested by using SPSS 17.0 Program, and to test the significance level, t-test was employed. The results elucidate the users were gratified in information, entertainment, and social interaction motives. Meanwhile, in economic and convenience motives, the users' gratification was not achieved. Then, there is no difference in the gratification level of Tokopedia.com and Bukalapak.com users. The discrepancy level between motives and users' gratification in the information, comfortability, entertainment, social interaction, and economic dimension yields no significant score.
\end{abstract}

Keywords-Uses and gratification, online, marketplace, motives

\section{Introduction}

\subsection{The background of the study}

Nowadays, E-commerce (electronic commerce) becomes the prominent trend [1] and significantly grows around the globe [2] [3]. It is comprehendible as an activity of marketing products through internet by exchanging information between the merchants and buyers [4]. Another expert [5] explains e-commerce as the use of internet and the web to transact business, in other words, e-commerce is doing trade or business transactions using internet and web as the media. Other experts state that ecommerce is the series of commercial activities partly or entirely using internet as the media of communication [6]. This is mentioned partly or entirely because the activities are very varied. There are those who use internet as the media of trade activities from the production process, advertisement, sales, payments, shipping and bookkeep- 
ing. On the other hand, there are those who only use internet as the media of sales process partly. In Indonesia, e-commerce is often called online trading business [7].

The rapid growth of online business has successfully attracted the interest of the public in Indonesia even though it is still regarded as a new thing [8]. It is also recognized by the Nielsen survey institution [9] with the increasing number of advertising budget in "online service" category in television. Nielsen recorded, in the first semester of 2013, advertising budget in online service increased to $82 \%$, and in the same period in 2014 and 2015 each, increased to $85 \%$ and $91 \%$. Nielsen wrote, there are 10 top-players e-commerce players in television since 2013, such as Tokobagus, Berniaga, Elevania, Traveloka, Tokopedia, Blibli, OLX, Lazada, Bukalapak, and Trivago[9]. It assumes that the phenomenon of e-commerce development in Indonesia is supported by the high number of internet user and consumer trends in this area.

Nowadays, internet usage has touched almost every line of business, every kind of industry and institution, and also has touched personal life of its users [10]. Then, there is no doubt that the number of users always gets increased extremely from year to year. The major factor which contributes to this rapid internet growth is the potential of e-commerce or trade transaction through internet [11] [12]. Moreover, this is also reinforced by the arguments that one of six internet users has sold something online [13]. The other reason is internet can be used by marketers to reach their audiences [14]. Obviously, this also has real and relevant argument that is the goods traded through internet is quicker to sell than offered conventionally.

According to [15], one of the dominant factors which motivates people to do online shopping is convenience (saving time and money), the cheaper price, and the many various choices. Japan and China are countries which have online market places in the top ten in the world [16]. The data showed the popularity of online marketplaces which surpasses online retailer in e-commerce. For online consumers in Indonesia, this kind of online e-commerce marketplace gives an opportunity for individual merchants or small-medium enterprises to be able to compete in global trading, whereas, for the buyer, this kind of e-commerce provides a large choice of products. The buyers are able to compare the products with features provided by the marketplace website, for instance compare the price of the same products. Furthermore, the buyers also could read the reviews from other buyers about the merchant or the products which could be used as reference to do transactions.

The marketplace providers have a role as facilitator to facilitate legal meeting and transaction between the buyers and merchants [17] by the help of internet as the medium [18]. Competitive advantage in online marketplace generally does not come from offered products or the price by the sellers in that site but comes from the various information and contents in that market place website [19]. The successful online business is generally measured by the high number of customers which use that site.

There are several previous studies which are relevant to this study. The first,[20] attempted to investigate consumers' motives doing online shopping in Asia, specifically in Malaysia. The majority of respondents who had been shopping online were women. This research finding was in contradiction to the research finding about internet in the developed countries previously found that most of online shopping buyers tend to be men. Furthermore, [21] in their research, they try to clarify the motives, 
attitude and gratification from commercial websites, and also the correlation between elements. The result of this study showed that 296 people responded to the question about their reasons for using commercial sites and what is the gratification they get from commercial website access experience. The other scholars also conducted a research to see the behavior of consumer in one of online marketplace in Indonesia, which is Lazada Indonesia [22]. Using questionnaire to gather the data from respondent living outside Java, they analyzed and drew conclusion that in online marketing activities, digital marketing efforts become prominent tools.

The study of online shopping behavior notes that the information content on websites is as important as the primary product that was sold in that website, in producing shopping traffic. The initial reason for customers visiting the site probably was caused by random browsing done by consumers, yet the content gratification could represent the consumers' reason to keep accessing the website. This could be understood as consumers perhaps coincidentally visiting the online shopping website, yet there is a particular characteristic in the online shopping website which motivates the consumers to stay or return to the website. From the explanation above, this study has an aim to discover consumers' motives and gratification in using online marketplace website through uses and gratification theory (UGT).

\section{Literature Review}

\subsection{Internet: The new media}

The internet has brought considerable change and innovation to our present life. This change has implications on many aspects of life, two of them are the presence of online journalism and advertisement with digital marketing or viral marketing[23]. Internet, as platform for new media, provides the collaboration of some aspects, such as between technology and social, political, and economic factors. Furthermore, [24] explains that the major status claim as new media and probably as mass media is the internet. From several series of new technologies, internet appeared in the mid1990s as new media, carrying significant change as unification of text, visual, and audio media brings several advantages in human life.

\subsection{Online marketplace: Tokopedia.com and bukalapak.com}

Online marketplace websites are one e-commerce form with a marketplace model. Marketplace is an electronic market performing buying and selling of goods or services, marketplace is considered a provider of mall online service, but the seller is not the site provider but a member who registers to the marketplace website to sell their products. The success of e-commerce with this marketplace concept is determined by the high number of sellers and consumers who joined in the e-commerce website.

There are two big e-commerce websites in Indonesia namely those are Tokopedia.com and Bukalapak.com. Both sites take the first and second positions in the type of online shopping website in Indonesia. These websites also have the same business 
model that is marketplace. Based on data from TV Adstensity, in 2016 Tokopedia.com and Bukalapak.com are the providers of online service with the highest advertisement budget in TV, namely Rp165 billion and Rp 128 billion.

Tokopedia.com is one of the first online shopping centers which supports a business marketplace model. It helps people, small stores and brands to open and manage online stores for free. In the first month of its release, in August 2009, Tokopedia only could grab 509 merchants with 4.560 members and the total transaction was Rp33 million. It offers a million products which divided into 25 big categories namely fashion for women, fashion for men, Muslim fashion, kids fashion, mobile phone and tablet, electronic, beauty, health, mother and baby, body care, households, gaming, laptop and accessories, computer and accessories, camera, automotive, sports, film and music, kitchen, office and stationery, souvenir, gift and presents, toys and hobby, food and beverages, books and software. Since its first launch, it firmly established itself as one of the e-commerce leaders in Indonesia. This was proved by statistic data that this website is always visited by 10 million of internet users in every month.

The other one, the competitor, Bukalapak.com is one of the well-known online marketplaces in Indonesia which provides media of trading, with consumer to consumer (C2C) business type. Everybody can start an online shop in Bukalapak and help the buyers from all over Indonesia for a single or many transactions. This site which has a mission to empower Small-Medium Enterprises (SME) or Usaha Kecil Menengah (UKM) was initially established in 2011 and had 25.000 merchants and 60.000 users. This number got significant growth in every year. As online shopping website included in the top 10 most visited sites in Indonesia, Bukalapak.com offers various products and services. Some categories exist in their website are e-voucher ticket, beauty and skincare, health, woman fashion, man fashion, mobile phone, computer, electronics, camera, hobby and collection, sports, bicycle, kids' fashion, baby stuffs, households, food, cars and accessories, motorcycle, industrial, stationery and voucher \& ticket.

\subsection{The theory of uses and gratification}

In communication theory, uses and gratification theory (UGT) pioneered by McQuail, Blumler and Brown generates the question of 'how and why' a media is utilized, and has the concern on viewers' gratification [25]. Moreover, in this theory it is assumed that the audience is active and conscious in selecting the media. Audiences are responsible for selecting media to complete their own needs. Media is considered as one of the factors how their needs are fulfilled.

Based on this theory, media consumers have the freedom to decide how they use the media and are independent to select what media is able to fulfill public's needs, and also how the media will affect the public themselves. This media selection applies to all types of media, either print or electronic media[26]. Generally, the basic assumption of UGT focuses on media public where the decision to use media is entirely in the hands of public until the end, they could decide to use media or not at all. Public is considered as an active agent who already have good media literacy, and under- 
stand the expected gratification and opportunities. Eventually, media that can to fulfill audiences' needs is called effective media [27].

\subsection{Gratification sought (GS) and gratification obtained (GO)}

The concept of consumer gratification divided into two, those are motives which are required or called gratification sought (GS) and satisfaction that is acquired or gratification obtained (GO). People's satisfaction in using media is eventually measured by the gap or the deviation between GO and GS. Gratification Sought (GS) is the individual desired satisfaction in using certain media. The motive in using media between one individual and another individual is different. The categories of users' motives based on [28] are as follows:

1. Information motive is the motive that includes the needs of valuable and useful information from internet

2. Convenience motive is defined as the ease for internet user until the internet users considering convenience as essential motives to utilize this medium

3. Social Interaction motive is the motive that refers to how far the internet users are willing to express themselves or having relationship with others in a virtual community

4. Entertainment motive is the motive that refers to how far the users look for pleasure, entertainment or joy when using internet

5. Economic motive is the motive that defines how the internet users employ internet to shopping and purchasing motivation. This motive also defines the medium to perform electronic transaction.

Gratification Obtained (GO) is a number of satisfactions that is gained by individual user because of completing various needs after they access the media. This gratification is measured by the completion of initial motive of gratification sought which underlies the individual in selecting which is the most satisfying online marketplace website. The indicator in determining gratification obtained is the same with the indicator in measuring gratification sought.

\subsection{UGT implementation in the new media and online market website}

The implementation of UGT is fit to the internet user's namely more interactive and individual[29]. Furthermore, [30] also emphasize that the approach of internet would be more informal and interpersonal than the former type of internet. This line is in tune with Ruggiero's idea [29] which states that the primary strength of UGT is its ability to permit researchers to investigate mediated communication situations via a single or multiple sets of psychological needs, psychological motives, communication channels, communication content, and psychological gratifications within a particular or cross-cultural context.

The growth of internet has resulted in the renaissance of uses and gratification tradition when scientists more attracted for more than only knowing who uses internet 
become interested in why they use this new media [31]. As a new media, internet still relates to traditional media in terms of uses and gratification[32]. In detail, people search internet for news with the same way when they use another kind of media for the necessity [31].Through those things, it is clearly visible that the media development offers people a multitude of different kinds of media choices with its own characteristic which is different with media in conventional era. Especially with active public concept which is found in the research that uses UGT where people or audience is considered as active and selective individual and also have a particular purpose related to the media which attract them, which means individual or audience as social creature has selective nature in receiving messages from the media. UGT is also appropriate to investigate the kind of site in internet [21]. This appropriateness is caused by many factors, such as: Active audience and interactivity, mutability, intentinal consumption of internet, and wide range of material online.

\section{Method}

This research employed a quantitative method. The population in this research is the students of a bachelor program of business and economy at the faculty of economic and business of Universitas Sumatera Utara (USU), Medan, Indonesia who ever made a purchase on Tokopedia.com and Bukalapak.com site. The selection was based on random results that researchers did using the drawing method. They are chosen because tertiary students are categorized as adults because they are 17 years or older. So, this group is assumed to be able to formulate their desires or needs that are met by using media, especially the internet. Their age (18-24 years) is assumed to be the age considered to be fast in keeping in touch with technological developments. According to [33], consumers born in the early 1970s to the late 1990s are referred to as millennial generation. This generation is characterized as being very adaptive to technological change [34] such as doing online shopping. The sampling technique employed in this research is the combination of purposive sampling and accidental sampling. For the criteria of purposive sampling, the students are registered in 2016 and the year before, and have ever purchased on both online marketplace sites at least once in the last 12 months. As the result, 66 respondents were taken as the sample.

This study used a set of questionnaire and survey to collect the data with the aim to discover the public's gratification on online marketplace websites in order to know which online marketplace is able to give optimal gratification to the users. This study is focused on discovering the differences of online e-commerce website gratification between Tokopedia.com and Bukalapak.com. The selection of those two online shopping websites was based on the ranking of e-commerce website released by alexa.com and the amount of television advertising shopping which released by those two websites in the first quarter in 2016. Tokopedia.com and Bukalapak.com are two very big e-commerce sites in Indonesia.

The instrument for collecting the data involved paper-based questionnaires employing direct answer question which consists of 49 questions dealing with exploring the pattern of the use of online marketplace (11 questions), consumer's motive (19 
questions), and consumer's gratifications (19 questions). The validity and reliability of the questionnaire were tested by using SPSS program for windows 17.0. The technique of analyzing the data in this research was through mean comparison. The tests on both mean were done to confirm the differences between the two mean that was significant differences and not just a coincidence. For testing the level of significance employed by using t-test for couple samples.

\section{$4 \quad$ Results}

\subsection{The characteristic of respondents}

The respondents' characteristics were reviewed by gender, monthly spending allowance (pocket money), and the duration of accessing internet. This showed a contrast difference, whereas if it is reviewed from age aspect, online shopping expenses and the frequency of purchasing on online shop did not show significant difference in the category of certain groups. The description below showed the characteristic of respondents.

Gender: The profile of gender showed $36.4 \%$ men and $63.6 \%$ women, there was contrast number: $27.2 \%$. The fact elucidated that women were higher than men in using online marketplace websites.

Table 1. Gender of respondents

\begin{tabular}{|c|c|c|c|}
\hline No & Gender & F & \% \\
\hline 1 & Men & 24 & 36.4 \\
\hline 2 & Women & 42 & 63.6 \\
\hline \multicolumn{2}{|c|}{ Total } & 66 & 100.0 \\
\hline
\end{tabular}

Age: The majority of respondents are between $18-21$ years old got (50 in total). 16 other respondents were $22-25$ years old. In the age characteristic, both groups were in the millennial groups. Millennial generation is the generation who is really adaptive in using technology, including online shopping.

Table 2. Respondents' age

\begin{tabular}{|c|c|c|c|}
\hline No & Age (years old) & F & \% \\
\hline 1 & $18-21$ & 50 & 75.8 \\
\hline 2 & $22-25$ & 16 & 24.2 \\
\hline 3 & $>=26$ & 0 & 0 \\
\hline & Total & 66 & 100.0 \\
\hline
\end{tabular}

Monthly spending allowance: The respondents who have monthly spending allowance Rp. 500.000 - Rp. 1.500 .000 and Rp. 1.500.001 - Rp. 3.000.000 each number of them are 42 and 11 . The cumulative both of them attain to $53 \%$, interpreting the majority total. Other respondents with lower allowance are $11 \%$ and the higher ones are $1 \%$. Based on the analysis, respondents with the average allowance Rp. $500.000-$ 
Rp. 1.500.000, Rp. 1.500.001 - Rp. 3.000.000 and Rp. 3.000.000, having parents'professions such as governmental officer, private employee and entrepreneur. Whereas, the respondents with allowance $\mathrm{Rp}$. 500.000 typically having parents' profession as civil servants and entrepreneur.

Table 3. Respondents' monthly spending allowance

\begin{tabular}{|c|c|c|c|}
\hline & Allowance (Rp) & F & \% \\
\hline No & & & \\
\hline 1 & $<500.000$ & 12 & 18.2 \\
\hline 2 & $500.000-1.500 .000$ & 42 & 63.6 \\
\hline 3 & $1.500 .001-3.000 .000$ & 11 & 16.7 \\
\hline 4 & $>3.000 .000$ & 1 & 1.5 \\
\hline \multicolumn{2}{|c}{} \\
\hline
\end{tabular}

Online shopping expenses: The total of respondents with minimal online shopping expenses less than Rp. 500.000 is $58 \%$. The group of these respondents most likely did purchase on online shopping website to buy fashion stuffs. While, the group of respondents with online shopping expenses Rp. 500.001-Rp. 1.500 .00 is $8 \%$.

Table 4. Respondents' online shopping expenses

\begin{tabular}{|c|c|c|c|}
\hline No & Expenses (Rp) & F & \% \\
\hline 1 & $<500.000$ & 58 & 87.9 \\
\hline 2 & $500.000-1.500 .000$ & 8 & 12.1 \\
\hline \multicolumn{2}{|c|}{ Total } & 66 & 100.0 \\
\hline
\end{tabular}

The duration of accessing internet per day: The numbers of respondents who accessed internet for $2-4$ hours a day is $18 \%$, for $5-8$ hours a day is $27 \%$, more than 8 hours a day is $14 \%$ and less than 2 hours a day is $7 \%$. The analysis elucidated that respondents who accessed internet less than 2 hours is the smallest number, and when this is accumulated with the respondents who accessed internet more than 2 hours, it reached $59 \%$. It could be concluded that the majority respondents accessed internet for more than 2 hours a day.

Table 5. Respondents' duration of accessing internet per day

\begin{tabular}{|c|c|c|c|}
\hline No & The Duration of Accessing Internet per Day (hours) & F & $\mathbf{\%}$ \\
\hline 1 & $<2$ & 7 & 10.6 \\
\hline 2 & $2-4$ & 18 & 27.3 \\
\hline 3 & $5-8$ & 27 & 40.9 \\
\hline 4 & $>8$ & 14 & 21.2 \\
\hline \multicolumn{2}{|c|}{ Total } & 66 & 100.0 \\
\hline
\end{tabular}

The duration per visit: The duration of visiting online marketplace website showed various numbers. The period approximately 2 hours on Tokopedia.com and Bukalapak.com is $54 \%$ and $53 \%$ respondents; the duration about 2 -4hours on To- 
kopedia.com and Bukalapak.com is $12 \%$ and $11 \%$ respondents; the visit duration 5 8 hours on Tokopedia.com is zero whereas on Bukalapak.com is 2 respondents.

Table 6. Respondents' duration of visit

\begin{tabular}{|c|c|c|c|c|c|}
\hline \multirow{2}{*}{ No } & Duration per visit (hours) & \multicolumn{2}{|c|}{ Tokopedia.com } & \multicolumn{2}{c|}{ Bulakapak.com } \\
\cline { 3 - 6 } & & $\boldsymbol{F}$ & $\boldsymbol{\%}$ & $\boldsymbol{F}$ & $\boldsymbol{\%}$ \\
\hline 1 & $<2$ & 54 & 81.8 & 53 & 80.3 \\
\hline 2 & $2-4$ & 12 & 18.2 & 11 & 16.7 \\
\hline 3 & $5-8$ & 0 & 0.0 & 2 & 3.0 \\
\hline \multicolumn{2}{|c|}{ Total } & 66 & 100.0 & 66 & 100.0 \\
\hline
\end{tabular}

The shopping frequency: The shopping frequency in last 12 months on online marketplace website showed: on Tokopedia.com and Bukalapak.com is 56\% and 61\% respondents shopping $1-3$ times; $9 \%$ and 4\% respondents shopping $4-6$ times; respondents shopping $6-9$ times only found on the respondents of Bukalapak.com that is $1 \%$; while respondents shopping more than 9 times only found on the respondents of Tokopedia.com that is $1 \%$.

Table 7. Respondents' shopping frequency in last 12 months

\begin{tabular}{|c|c|c|c|c|c|}
\hline \multirow[t]{2}{*}{ No } & \multirow[t]{2}{*}{ The shopping frequency in last 12 months (hours) } & \multicolumn{2}{|c|}{ Tokopedia.com } & \multicolumn{2}{|c|}{ Bulakapak.com } \\
\hline & & $F$ & $\%$ & $\boldsymbol{F}$ & $\%$ \\
\hline 1 & $1-3 x$ & 56 & 84.8 & 61 & 92.4 \\
\hline 2 & $4-6 x$ & 9 & 13.6 & 4 & 6.1 \\
\hline 3 & $6-9 x$ & 0 & 0.0 & 1 & 1.5 \\
\hline 4 & $>9 \mathrm{x}$ & 1 & 1.5 & 0 & 0.0 \\
\hline & Total & 66 & 100.0 & 66.00 & 100.0 \\
\hline
\end{tabular}

\subsection{GS and GO for Bukalapak.com}

The result of the analysis presented that Bukalapak.com only could fulfill its users' gratification in the dimension of information, entertainment, and social interaction. This could be seen from the deviation point of GS score and GO score which have positive value. In the dimension of information, GS and GO score of Bukalapak.com users have the same point those were GS 3.11 and GO 3.11. This means all needs of Bukalapak.com users in the dimension of information were accomplished. Thus, it could be concluded that the gratification of Bukalapak.com users in the dimension of information were reached. As the statements above, the users' gratification of Bukalapak.com consisted of four statements, those are: (1) Able to get information which is unknown before about to the products they are looking for/ will be bought, (2) Able to observe the products which are looking for, (3) Able to understand the possible value to get from online shopping, (4) Able to update the information of products.

While, in the dimension of entertainment and social interaction, the deviation between both dimensions were really close, that was 0.1 (the deviation of entertainment motive was 0.15 point and the deviation of social interaction motive was 0.16 point). This revealed that the users' gratification in both dimensions was almost the same. 
Then, the gratification in the dimension of gratification consisted of four statements, those were: (1) Able to look around a lot of products, (2) Able to visit online marketplace website easily, (3) Feeling pleasant to be at the shop even if it is online, and (4) Feeling amused by seeing many kinds of products.

On the other hand, in the dimension of social interaction, the users' gratification included four statements, those are: (1) Able to update and follow trends of products, (2) Able to express their opinions and responses in online shopping forum, (3) Able to meet digitally with the same community, and (4) Able to augment business relationship or connections.

Based on the deviation number of GS and GO score on Bukalapak.com, could be seen that the users' gratification in the dimension of convenience and economic still not accomplished. This is proved by the number of deviations on minus position. The deviation point in the dimension of convenience seemed the longest one, that was 0.22 , besides that, the deviation point of economic dimension reached -0.16 . As for the statement of gratification accomplishment in the dimension of convenience consisted of: (1) Able to get complete information about the products, (2) Able to find various kinds of wanted products, (3) Able to explore numerous kinds of products until it is done or finished, and (4) Able to manage the limited time to do online shopping.

Besides, in the dimension of economic motive, the unaccomplished gratification consisted of three statements, those were: (1) able to get product with more economical price, (2) able to get import products practically so eventually more economical, and (3) able to exploit and take advantage of e-banking.

The comparison of GS and GO score of Bukalapak.com elaborated through the table below.

Table 8. The comparison of GS and GO score of Bukalapak.com

\begin{tabular}{|c|c|c|c|c|}
\hline No & Motives & GS & GO & Deviation \\
\hline 1 & Information & 3.11 & 3.11 & 0 \\
\hline 2 & Convenience & 3.29 & 3.07 & -0.22 \\
\hline 3 & Entertainment & 2.93 & 3.08 & 0.15 \\
\hline 4 & Social Interaction & 2.84 & 3.00 & 0.16 \\
\hline 5 & Economy & 3.15 & 2.99 & -0.16 \\
\hline
\end{tabular}

\subsection{GS and GO for Tokopedia.com}

According to the data, Tokopedia.com was unable to accomplish all expectations of gratification fulfillment of its users. In convenience and economic motives, the deviation between GO point and GS point could be seen which is on minus position. In convenience motives, Tokopedia.com got GS score 3.29 and GO score 3.10. Tokopedia.com got GS score $>$ GO score, it means that in the dimension of convenience and gratification of Tokopedia.com users still not fulfilled. As for the statement of gratification accomplishment in the dimension of convenience consists of: (1) Able to get complete information about the products, (2) Able to find various kinds of wanted 
products, (3) Able to explore numerous kinds of products until it is done or finished, and (4) Able to manage the limited time to do online shopping.

In the economic motives, Tokopedia.com got GS score 3.17 and GO score 3.01. In this dimension, the users also did not get gratification in using Tokopedia.com for online shopping. Whereas, the economic motives in this dimension quite high by getting GS score 3.71 which were bigger than GS score in entertainment motive. As for the unaccomplished economic gratification from Tokopedia.com consisting three statements, those were: (1) Able to get product with more economical price, (2) Able to get import products practically so eventually more economical, and (3) Able to exploit and take advantage of e-banking.

For informative motive, Tokopedia.com received a GS score and GO score with a very narrow deviation that is 0.01 with GS score 3.10 and GO score 3.11. This showed that the needs of all its users were accomplished. From the very thin deviation point, could be concluded that there was no gap. Yet, it also could be concluded that the gratification of its users in the dimension of information was fulfilled. The gratification of information consisted of four statements, as follows: (1) Able to get information which is unknown before about to the products they are looking for/ will be bought, (2) Able to observe the products which are looking for, (3) Able to understand the possible value to get from online shopping, and (4) Able to update the information of products.

The gratification of Tokopedia.com users was achieved from entertainment and social interaction motives, when compared to informative, convenience and economic motive, the GS score achieved from these two dimensions quite low that was entertainment motive got GS score 2.96 and social interaction motive got GS score 2.73. Even though, getting quite low GS score, yet the users' gratification in these two dimensions was achieved. With the GO score achieved was bigger than GS score where the GO score in entertainment motive was 3.09 and GO score in social interaction motive was 2.96 .

The gratification of entertainment of Tokopedia.com users consisted of four statements, as follows: (1) Able to look around a lot of products, (2) Able to visit online marketplace website easily, (3) Feeling pleasant to be at the shop even if it is online, and (4) Feeling amused by seeing many kinds of products.

On the other hand, in the dimension of social interaction, the users' gratification including four statements, those are: (1) Able to update and follow trends of products, (2) Able to express their opinions and responses in online shopping forum, (3) Able to meet digitally with the same community, and (4) Able to augment business relationship or connections.

The comparison GS and GO score of Tokopedia.com was described by the table below. 
Paper-The Use of Online Marketplace Websites in Indonesia: A Study of Consumers' Motives...

Table 9. The comparison of GS and GO score of Tokopedia.com

\begin{tabular}{|c|c|c|c|c|}
\hline No & Motives & GS & GO & Deviation \\
\hline 1 & Information & 3.10 & 3.11 & 0.01 \\
\hline 2 & Convenience & 3.29 & 3.10 & -0.19 \\
\hline 3 & Entertainment & 2.96 & 3.09 & 0.13 \\
\hline 4 & Social Interaction & 2.73 & 2.96 & 0.23 \\
\hline 5 & Economy & 3.17 & 3.01 & -0.16 \\
\hline
\end{tabular}

\subsection{The assessment of comparison test}

Based on the result of paired t-test for the couple of motives (GS) and gratification (GO) of Tokopedia.com discovered: (1). In the dimension of information, there was no significant difference, between GS score and GO score, with score P (0.765) > 0.05 . This means that GS score and GO were regarded as the same. As the result, there was no gap between informative motive and the gratification of information of Tokopedia.com users. (2). In the dimension of convenience, entertainment, social interaction and economic, got the value of $\mathrm{P}(0.001 ; 0.019 ; 0.012 ; 0.018)<0.05$, which means in those four of dimensions, there were significant differences.

So, it could be concluded that in the dimension of convenience, entertainment, social interaction and economic, there were the gap of gratification of Tokopedia.com users.

According to the result of paired t-test for the couple of motive (GS) and gratification (GO) of Bukalapak.com known as follows: (1). In the dimension of information, there was no significant difference, between GS score and GO score, with score P $(1.000)>0.05$. This means that GS score and GO were regarded as the same. As the result, there was no gap between informative motive and the gratification of information of Bukalapak.com users. (2). In the dimension of convenience, entertainment, social interaction and economic, got the value of $\mathrm{P}(0.001 ; 0.003 ; 0.049 ; 0.036)<0$. 05 , which means in those four of dimensions, there were significant differences.

So that could be concluded, in the dimension of convenience, entertainment, social interaction and economic were the gap of gratification of Bukalapak.com users.

\section{Discussion}

Based on the calculation of GS and GO, apparently, there was no significant difference found in the average of informative motives and the average of informative gratification on both online marketplace websites, Tokopedia.com and Bukalapak.com. This means that the needs of expectation that would be sought equal with the expectations that would be obtained, so that there was no gap and could be concluded that informative gratification of Tokopedia.com and Bukalapak.com was accomplished.

According to the theory of uses and gratification, informative gratification is a principal regulator which affects the users of particular media [35]. Furthermore, the quality of information of a website has direct effect on the consumers' perception about that website, so they form a user's attitude toward the website [36]. This is also 
supported by [37] clarifying that the media users considering the media's ability in delivering information needed is the fundamental reason to accept the media itself.

The calculation of GS and GO score in this study also brought up an interesting finding that in entertainment motive and social interaction motive on Tokopedia.com and Bukalapak.com website, the users have been gratified successfully by the media. Whereas, the convenience motive and economic motive on both online marketplace websites, the users have been failed to be gratified by the media. This finding was certainly very interesting, looking at the previous research, economic motive positively impacts to the online marketplace website. Likewise, the motive of convenience, in the research of [38], it was found that the convenience motive is the significant predictor on an online marketplace website. Moreover, [28]explains that the users with strong economy situation and the motive of convenience would like to visit the online shop more often. Yet, in this research, the economic and convenience gratification apparently was not obtained by the media users. This is in line with the research of [21] who conducted the research in Egypt. They discovered that the economic and convenience gratification did not find on commercial website (online shopping). The online marketplace website was used as an entertainment media for source of shopping information while, the strong gratification of social interaction of Egyptian consumers were influenced by cultural factors. Thus, using commercial website could be greatly influenced by cultural factors.

The research of [39] showed that $80 \%$ of Indonesian consumers still use online marketplace websites to see reviews of wanted products before purchasing offline. This was caused by a lot of Indonesia consumers who still do not believe in the system of online transaction and to give the information related to their credit card. The finding of [40] revealed that the majority participants of online shopping did the payments through ATM was $36,7 \%$. This means online marketplace websites are still not trusted by Indonesian consumers. These numerous reasons motivate the users to use this website as entertainment media or make interaction with online community.

\section{Conclusion}

Based on the data analysis, the conclusion could be drawn that on an online marketplace website, the users' gratification in the motives of information, entertainment and social interaction was achieved. Whereas in the motives of convenience and economic, the gratification of users was not achieved. Furthermore, there was no different level of gratification between Tokopedia.com and Bukalapak.com users. The different gap value between motives and gratification of users in all dimensions such information, convenience, entertainment, social interaction and economic dimension resulted in an insignificant score.

\section{$7 \quad$ Limitation of the Study}

Since this research is limited to the university students, there is a need to explore the other areas such as the gratification of senior high school students as the consumer 
of online marketplace, the consumers' loyalty in using online marketplace website, and the effect of service given by online marketplace and consumers' satisfaction. It is also suggested to the online marketplace managers to gradually make innovation in order to keep the quality and fulfill the consumers' need.

\section{Acknowledgement}

The writers would like address their sincere gratitude to Universitas Sumatera Utara.

\section{References}

[1] M. Ijaz and J. Rhee, "Constituents and Consequences of Online-Shopping in Sustainable E-Business: An Experimental Study of Online-Shopping Malls,” Sustainability, vol. 10, no. 10, pp. 3756-3799, Oct. 2018. https://doi.org/10.3390/su10103756

[2] O. Ghazali et al., "Cloud-Based Global Online Marketplaces Review on Trust and Security,” Int. J. Interact. Mob. Technol., vol. 13, no. 04, pp. 96-116, Apr. 2019.

[3] S. Singh, I. A. Zolkepli, and W. K. Cheah, "New Wave in Mobile Commerce Adoption via Mobile Applications in Malaysian Market: Investigating the Rela-tionship Between Consumer Acceptance, Trust, and Self-Efficacy," Int. J. Interact. Mob. Technol., vol. 12, no. 7, pp. 112-127, Nov. 2018. https://doi.org/10.3991/ijim.v12i7.8964

[4] L. E. Boone and D. L. Kurtz, Pengantar Bisnis Kontemporer, 11th ed. Jakar-ta: Salemba Empat, 2008.

[5] K. C. Laudon and J. P. Laudon, Sistem Informasi Manajemen, 10th ed. Ja-karta: Salemba Empat, 2008.

[6] N. W. Sakti, Buku Pintar Pajak E-Commerce: Dari Mendaftar Sampai Membayar. Jakarta: Visi Media, 2014.

[7] M. Nisrina, Bisnis Online: Manfaat Media Sosial Dalam Meraup Uang. Ja-karta: PT. Buku Kita, 2015.

[8] Sfenrianto, I. Oliver, A. Christiano, and M. P. Mulani, "Impact of E-Service on Customer Loyalty in Marketplace in Indonesia," Journal of Theoretical and Applied Information Technology, vol. 96, no. 20, pp. 6795-6805, 2018.

[9] "BELANJA IKLAN NAIK 6\% DI KUARTAL KEDUA 2015 - Nielsen," 09-Aug-2015. [Online]. Available: https://www.nielsen.com/id/en/press-releases/2015/Belanja-IklanNaik-6-persen-di-Kuartal-Kedua-2015/. [Accessed: 21-Jul-2019].

[10] H. Kartajaya, Indonesia Wow, Markplus Wow, We Are Wow. Jakarta: PT. Gramedia Pustaka Utama, 2015.

[11] W. J. Severin and J. W. Tankard, Teori Komunikasi : Sejarah, Metode, dan Terapan didalam Media Massa. Jakarta: Kencana Prenada Media Group, 2005.

[12] B. Al-Fawwaz, A. M. Al-Shatnawi, and W. S. AlSharafat, "Recognizing the Importance of Brand Awareness on E-commerce Sales while Shopping on Inter-net: Empirical Analysis of European Countries,” Int. J. Interact. Mob. Technol., vol. 9, no. 1, pp. 15-18, Jan. 2015. https://doi.org/10.3991/ijim.v9i1.4111

[13] S. Biagi, Media / Impact Pengantar Media Massa, 9th ed. Jakarta: Salemba Humanika, 2010. 
[14] Z. F. González Romo, I. García-Medina, and N. Plaza Romero, "Storytelling and Social Networking as Tools for Digital and Mobile Marketing of Luxury Fash-ion Brands,” Int. J. Interact. Mob. Technol., vol. 11, no. 6, pp. 136-149, Nov. 2017. https://doi.org/10.3991/ ijim.v11i6.7511

[15] N. Delafrooz, L. H. Paim, and A. Khatibi, "Students' Online Shopping Be-havior: An Empirical Study," Journal of American Science, vol. 6, no. 1, pp. 137-147, 2010.

[16] R. Ardianti, Perkembangan Adopsi E-commerce dan Implikasinya bagi Ma-najemen Organisasi Bisnis. Surabaya: Universitas Kristen Petra, 2010.

[17] M. Majid, "Mencermati Perbedaan Toko Online dan Marketplace." [Online]. Available: https://www.maxmanroe.com/mencermati-perbedaan-toko-online-dan-marketplace.html. [Accessed: 21-Jul-2019].

[18] G. Anyanwu, O. Nelson, and A. Salawu, "Online Advertising Influence for Promoting Preference for E-Shopping in Nigeria: A Study of Jumia," Academy of Strategic Management Journal, vol. 17, no. 6, pp. 1-9, 2018.

[19] T. F. Stafford, Motivations Related Csotumer Use of Online Services. Arling-ton: University of Texas Arlington, 2001.

[20] W. M. Lim and D. H. Ting, E-shopping: An Analysis of the Uses and Gratifi-cations Theory. Kuala Lumpur: Monash University, 2012.

[21] A. E. Mahmoud, P. Klimsa, and P. J. Auter, "Uses and Gratifications of Commercial websites in Egypt: Towards a new mode," Journal of Arab \& Muslim Media Research, vol. 3, no. 1, pp. 99-120, 2010. https://doi.org/10.1386/jammr.3.1-2.99_1

[22] H. B. Winarko and A. T. Manshur, "The online consumer behavior outside Java Island: A case study of Lazada Indonesia,” IJRSM, vol. 7, no. 1, pp. 47-58, Mar. 2018. https://doi. org/10.5861/ijrsm.2018.3001

[23] M. Nurlatifah, "Mencari Arah Tranformasi Kebijakan Media di Indonesia," in Ilmu Sosial di Indonesia: Perkembangan dan Tantangan, Jakarta: Yayasan Pustaka Obor Indonesia., 2016. https://doi.org/10.17510/wjhi.v13i1.19

[24] D. McQuail, Teori Komunikasi Massa. Jakarta: Salemba Humanika, 2011.

[25] Humaizi, "The Correlation between Broadcasting Spill-Over of Malaysian Television and Radio on Islamic Religious Knowledge of Community Members in East Aceh," JKMJC, vol. 34, no. 1, pp. 202-217, Mar. 2018. https://doi.org/10.17576/jkmjc-2018-3401-12

[26] S. W. Littlejohn and K. A. Foss, Teori Komunikasi. Jakarta: Salemba Hu-manika, 2011.

[27] R. Kriyantono, Teknik Praktis Riset Komunikasi. Jakarta: Kencana Prenada Media Group, 2010.

[28] J. Filipović, "The Attractiveness of Different Online Formats Motives and Frequencies of Use,” Digiworld Economic Journal, vol. 89, no. 1, pp. 105-115, 2013.

[29] T. E. Ruggiero, "Uses and Gratifications Theory in the 21st Century," Mass Communication \& Society, vol. 3, no. 1, pp. 3-37, 2000.

[30] H. Dicken-Garcia, "The Internet and Continuing Historical Discourse," Jour-nalism \& Mass Communication Quarterly, vol. 75, no. 1, pp. 19-27, Mar. 1998. https://doi.org/ $\underline{10.1177 / 107769909807500105}$

[31] R. West and L. H. Turner, Pengantar Teori Komunikasi: Analisis dan Ap-likasi. Jakarta: Salemba Humanika, 2010

[32] J. Dimmick, Y. Chen, and Z. Li, "Competition Between the Internet and Traditional News Media: The Gratification-Opportunities Niche Dimension," Jour-nal of Media Economics, vol. 17, no. 1, pp. 19-33, Jan. 2004. https://doi.org/10.1207/s15327736me1701_2

[33] M. R. Solomon, Consumer Behavior: Buying, Having and Being, 10th ed. New Jersey: Pearson Education, 2013.

[34] T. Suryani, Perilaku Konsumen di Era Internet. Yogyakarta: Graha Ilmu, 2013. 
[35] M. M. Luo and W. Remus, "Uses and Gratifications and Acceptance of Web-based Information Services: An Integrated Model," Computers in Human Behaviour, vol. 38, pp. 281-295, 2014. https://doi.org/10.1016/j.chb.2014.05.042

[36] Z. ul Haq, "E-mail advertising: A study of consumer attitude toward e-mail advertising among Indian users,” J Retail Leisure Property, vol. 8, no. 3, pp. 207-223, Aug. 2009. https://doi.org/10.1057/rlp.2009.10

[37] R. A. Bauer and S. Greyser, Advertising in America: The Consumer View. Boston: Harvard University, 1968.

[38] H. Ko, C.-H. Cho, and M. S. Roberts, "Internet Uses and Gratifications: A Structural Equation Model of Interactive Advertising," Journal of Advertising, vol. 34, no. 2, pp. $57-$ 70, 2005. https://doi.org/10.1080/00913367.2005.10639191

[39] Nielsen, "Konsumen Indonesia Mulai Menyukai Belanja Online," Press Room, 09-Mar2014. [Online]. Available: https://www.nielsen.com/id/en/press-releases/2014/konsumenindonesia-mulai-menyukai-belanja-online. [Accessed: 26-Jul-2019].

[40] APJII, Penetrasi dan Perilaku Pengguna Internet 2016. Jakarta: APJII, 2016.

\section{Authors}

Humaizi is an associate professor at communication studies department, Faculty of Social and Political Sciences, Universitas Sumatera Utara, Medan, Indonesia. His specialization is in the area of mass and human communication. He could be reached at humaizi fisipusu@yahoo.com or humaizi@usu.ac.id.

Sakhyan Asmara is a senior lecturer at communication studies department, Faculty of Social and Political Sciences, Universitas Sumatera Utara, Medan, Indonesia.

Rany Listiawati Sis is a graduate from communication studies department, Faculty of Social and Political Sciences, Universitas Sumatera Utara, Medan, Indonesia.

Muhammad Yusuf is a lecturer at Faculty of Cultural Sciences, Universitas Sumatera Utara, Medan, Indonesia.

Article submitted 2019-07-27. Resubmitted 2020-01-22. Final acceptance 2020-01-23. Final version published as submitted by the authors. 